\title{
Technologies in the education of children and teenagers with autism: evaluation and classification of apps by work areas
}

\author{
Carmen del Pilar Gallardo-Montes ${ }^{1}$ (D) - María Jesús Caurcel Cara ${ }^{2}$. \\ Antonio Rodríguez Fuentes ${ }^{1}$ (D)
}

Received: 21 July 2021 / Accepted: 1 October 2021 / Published online: 16 October 2021

(c) The Author(s) 2021

\begin{abstract}
Mobile apps represent a resource with great potential for encouraging the development of many skills, given the high number of apps available and the quick access to them. Many professionals and families include these resources in the education and therapy of children with autism. For a group with such particular needs, a review of the apps is great importance, since, due to their characteristics, the apps must provide content, design and pedagogical aspects that fit those needs. Through a previously validated system of indicators, 155 free apps on Google Play were evaluated, using "autism" in English and in Spanish. We determined which work area each app developed, as well as which were the most multifaceted. Having evaluated the recorded data, we calculated frequencies, percentages and reliability, as well as parametric contrast and correlation statistics. We found that the focus of most apps was on executive functions, language and entertainment, with a minority devoted to the emotional sphere or time management. However, $98.06 \%$ of the apps worked on several areas, which makes them more functional but with the downside of not being specialized. Most apps were placed in the "recommendable" level but with margin for improvement in increasing their functionality.
\end{abstract}

Keywords Special education · Autism · Educational technology $\cdot$ Appropriate technology $\cdot$ Assessment $\cdot$ Mobile learning resources

María Jesús Caurcel Cara

caurcel@ugr.es

Carmen del Pilar Gallardo-Montes

cgallardo@ugr.es

Antonio Rodríguez Fuentes

arfuente@ugr.es

1 Department of Didactics and School Organization at the Faculty of Education, University of Granada (Spain), Campus "La Cartuja" s/n, 18071 Granada, Spain

2 Department of Developmental and Educational Psychology at the Faculty of Education, University of Granada (Spain), Campus "La Cartuja" s/n, 18071 Granada, Spain 


\section{Introduction}

Autistic Spectrum Disorder (ASD) is characterized by the presence of impairments and difficulties in areas connected to communication and social interaction, along with restrictive patterns with respect to diversity of behaviours and interests (APA, 2014). Autism is a part of ASD, according to the APA manual. Wing (1998) defines it as a set of symptoms associated with three dimensions (autistic triad): impairments and delay in language and communication, both verbal and non-verbal; impairments in the social sphere, more specifically in interpersonal reciprocity; and impairments in behaviour and thinking.

The global prevalence of people with autism has been measured by various authors and for various contexts, but the figures are not exact. Fortea et al. (2013) show that it could affect 60-70 of every 10.000 people; APA (2014) and March et al. (2018) state that it could comprise $1 \%$ of the population; Anzaldo and Cruz Ruiz (2019) assert that it affects one out of every 160 children in the world; and Málaga et al. (2019) show that in countries such as the United States it comprises one of every 59 children, and in Portugal, one of every 806. Even with this lack of agreement, the prevalence is notable. It is therefore important that these children are offered the care and education to enable their comprehensive and autonomous development from an early age. It is vital for professionals and specialists who participate in their education and/or psychopedagogical interventions to have the requisite training and means, including digital techonologies and material specifically designed for this group.

With this in mind, having searched through the different areas in which children and adolescents with this disorder have greater vulnerability - communication, language, emotions, basic instrumental skills, executive functions and time management - we observed that information and communications technology (ICT) in all its varieties (smartphone, tablet, communication boards, computers, etc.) achieves positive results in their enhancement and development. "Pupils with ASD often require the intervention of a wide range of services adapted to their specific needs" (Cappe et al., 2017, p. 498). Various studies (Castro \& Mallón, 2019; David et al., 2019; González et al., 2016; Guzmán et al., 2017; Hernández \& Sosa, 2018; Lorenzo et al., 2021; Pinel et al., 2018; Silva \& de Rodríguez, 2018; Terrazas et al., 2016; Tsikinas \& Xinogalos, 2020; Vlachou \& Drigas, 2017; Wang \& Xing, 2021) show the benefits that ICT offers this community, with a wealth of content focused on the comprehensive and specialized development of people with autism.

\subsection{Apps for children with ASD and autism}

In particular, apps provide a resource with great potential for working on and encouraging the development of many skills, given the high number of apps available and the quick and simple access to them (Gallardo-Montes et al., 2021a). Similarly, studies focused on children with autism using smartphone and tablet 


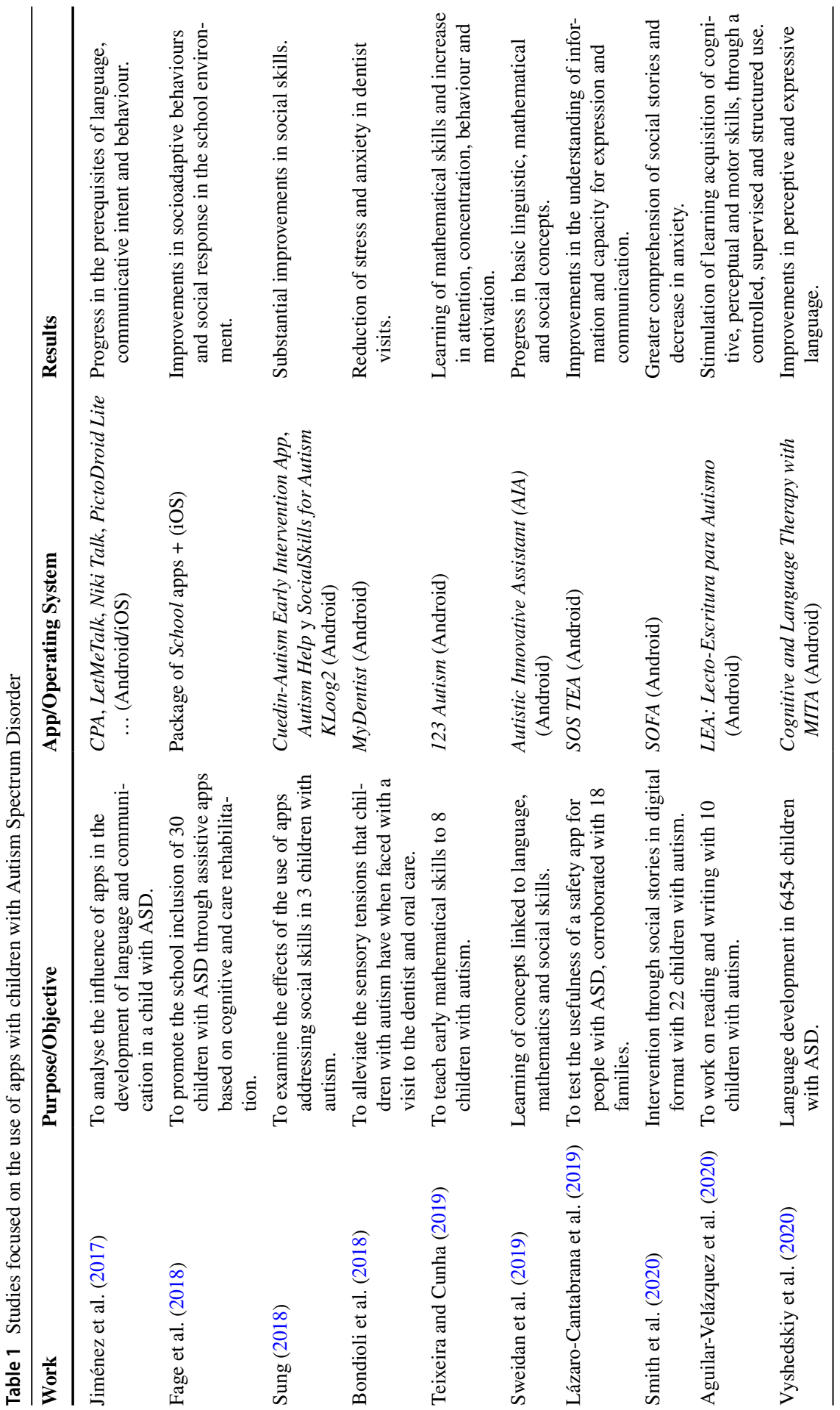


apps have been increasing, and many authors have described their experience and success in using them (Table 1).

As well as being a good option for entertainment for any section of society, apps have potential beyond mere recreation for children with autism. Their content, and the way it is laid out, is presented in a controlled way, without ups and downs or intimidating situations, which is favourable for children and adolescents with autism (González et al., 2016; Hernández \& Sosa, 2018; Terrazas et al., 2016). The digitalformat tasks are also attractive to the user (Lozano et al., 2013b; Suárez et al., 2015), offering visual stimuli that are highly appealing to children with autism (García et al., 2016; Hernández \& Sosa, 2018; Jiménez et al., 2017). In addition, authors such as García et al. (2016) and Jiménez et al. (2017) uphold the idea that interventions supported by apps facilitate and stimulate language and communication.

\subsection{Previous studies on the evaluation of apps}

Studies that examine apps for children and adolescents with functional diversity are numerous and varied. Cayton et al. (2015) assessed mathematics apps on the Apple App Store with regard to mathematical content, feedback, user interaction and adaptability. Crescenzi and Grané (2016) carried out a content analysis of 100 apps for children between the ages of six months and eight years old, examining their visual and interactive design, and they concluded that the quality of the aspects they measured was low. Larco et al. (2018) assess the quality of 73 apps on Google Play for people with disabilities, concluding that improvements were needed regarding personalization and interactivity. Kucirkova (2019) studied the design parameters of apps for creating children's stories. Crescenzi et al. (2019), in a systematic review of 200 apps for eight-year-old children, related to the safety and risks involved from an ethical perspective, underline the need to consider several aspects, including: mechanisms for protection; tools to change settings; stereotypes; knowledge held prior to using the app; and the verbal component presented. Leech et al. (2021) study mental health-focused apps for adolescents and young adults and the benefits following their use.

However, there are few studies that focus on the evaluation of apps for people with autism (Table 2). We need to pay attention to the particular areas in which people with this condition have greater difficulty, in order to find those apps that include suitable content based on their needs.

\subsection{Spheres or areas in which children and adolescents with autism present greater difficulty}

Children with autism exhibit significant impairments in the area of communication, along with many difficulties in language processing (Orellana, 2016; De Castro et al., 2018). As a consequence, there is impaired social interaction. ICT offers resources and tools that promote precisely the communication competence (Peirats et al., 2019). The software that supports language and communication makes it possible to create material that is connected to the communicative process through 


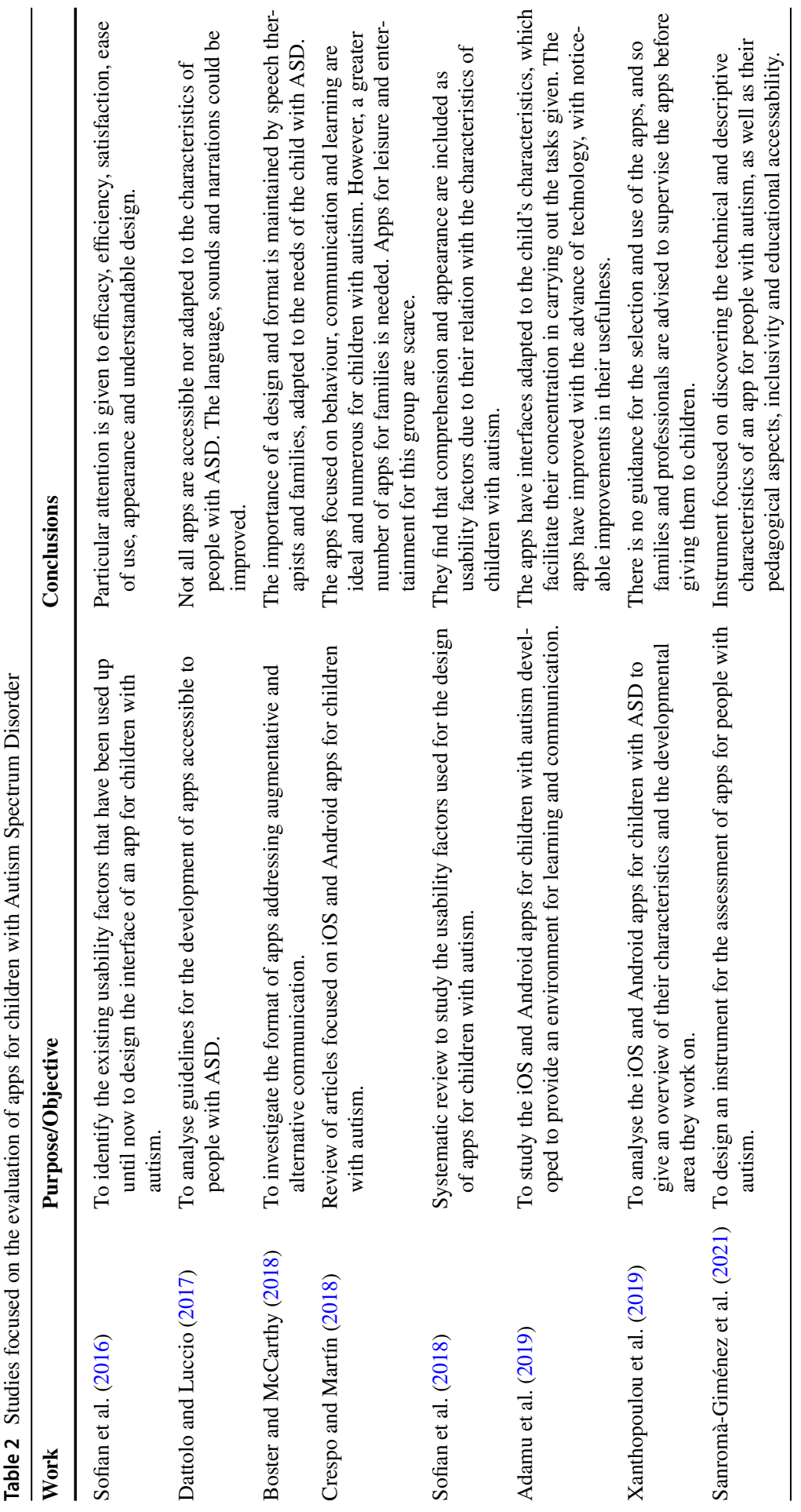




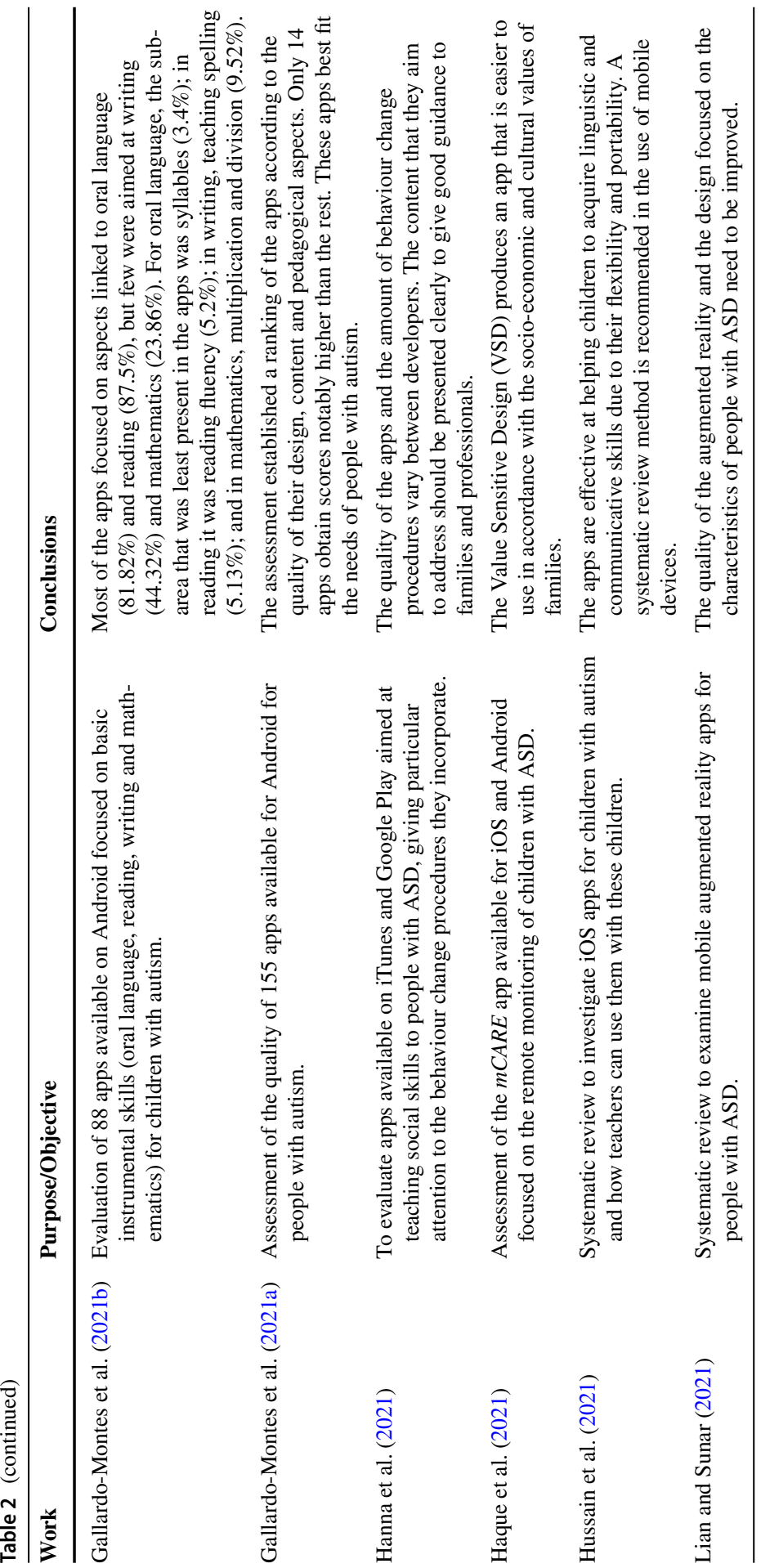


images, personal photographs and pictographs, enabling the user to create personalized schedules and social histories (Hernández \& Sosa, 2018). Thus it can be adjusted to the interests of the child, young person or adult with ASD, which is essential for motivating communicative interaction (Baixauli et al., 2017).

Regarding the emotional sphere, children and young people with autism have a diminished capacity for understanding mental representations (Pedreño et al., 2017). An example of this is their difficulty in comprehending emotions, beliefs and intentions (Mazza et al., 2017). Authors such as Lozano and Merino (2015) state that, through a structured and well planned intervention, it is possible to improve the emotional competences. Successful studies and experiences, such as those of Lozano et al. (2013a), González et al. (2016) and Matey (2017), show improvements in understanding emotions with the aid of technological resources and apps in children with autism. Thus, the appropriate and organized use of these types of resources can guide psychopedagogical interventions toward positive results.

Pouw et al. (2013) add that children and adolescents with autism present an impaired capacity to create a Theory of Mind (ToM), which is closely connected with social interaction. This theory addresses the ability of people to attribute mental states to oneself and to others, through which they can understand their own and others' behaviour (Premack \& Woodruff, 1978). ToM produces patterns or behaviours that enable a person's communicative and social development with their surrounding environment. Because processes integral to human development operate in ToM, an effort is made to promote them in people with autism from an early age. Some of the areas that converge in ToM are communication, language and the emotional sphere - the areas in which people with autism have most difficulty.

In terms of the basic instrumental skills, Íñiguez (2013) states that "instrumental learning is based on the acquisition of essential instruments and tools that are the basis for accessing the rest of knowledge and attaining an education of quality" (p. 1). People with autism display difficulties in learning these types of competence, such as artihmetic, writing and reading. Detecting these obstacles and treating them are two key aspects in intervening with children with autism.

"Learning to read and write is perhaps the first truly academic action in schools; it marks a before and after in the life of a child. Knowing how to read and write is, nowadays, something we expect of any person" (Autismo Diario, 2017, p. 1). The learning of reading and writing represents a step forward in development, since it gives an improved under-standing of language and its development. Pérez et al. (2012) stress that "teaching to read in autism does not only mean one step further in the natural process of education and culturalization. In autism, reading and writing can provide a way in for intervention on particularly affected aspects" (p. 85). In this regard, apps offer a large range of material to work on these concepts in a playful and active way.

In addition, people with autism exhibit difficulties in tasks connected with executive functions (Peirats et al., 2019). These involve the capacity for holding and managing information (working memory), prepotent response inhibition, flexibility to task change, planning to achieve objectives, and decision-making (Goldstein et al., 2014). "These processes are critical for our daily functioning, as they enable us to carry out independent, intentional and self-directed 
behaviour" (Martín et al., 2020, p.8). Authors such as Guzmán et al. (2017) state that digital resources open up a world of possibilities for working on the executive functions. The utilization of apps has therefore emerged as an interesting option, since it combines exercises for memory, organization and attention, along with entertainment and recreational activities.

The enjoyment of free time, in terms of leisure and entertainment, is vital for any person. Hence CeRMi (Spanish Committee of Representatives of Persons with Disabilities) declares that:

[...] leisure is a fundamental right that enables the personal and social development of people and which nobody should be deprived of because of disability. It is an essential medium for attaining emotional well-being, developing interpersonal relations and promoting the inclusion of people with disabilities. (2018, p.2)

Hence providing digital options to children and adolescents with autism represents an interesting and encouraging step forward for them. Along these lines, Villén (2017) describes the experience undertaken by including the videogame Minecraft as "an inclusive leisure alternative for people with ASD” (p. 13).

Therefore, having reviewed the literature, we can see how there is an abundance of studies focused on the benefits of ICT and, more specifically, on the values that apps have in the development of children with autism. Considering that these technological options are presented as groundbreaking and motivating support resources for the teaching-learning process, therapy and skill development, it would be interesting and worthwhile to find out precisely what apps are being offered to this community, what content they work on and their quality. This would help to guide and structure teaching and/or psychopedagogical interventions toward specific goals with certain guarantees for success.

A simple search of the app catalogue produces hundreds of apps for people with autism, but no prior knowledge or clue as to their purpose. According to the review of studies based on apps and autism, there has been no scientific undertaking to evaluate apps specifically for this community, nor has there been an analysis of all the free apps for Android available in the Google Play Store. We therefore intend to discover and recount the number of previous apps and assess their quality and variety. Consequently, this study has the following aims:

1. To discover and calculate the number, variety and quality of apps specifically created for children with autism that exist and are available for Android.

2. To evaluate the different free apps for children with autism available on Google Play Store according to predetermined criteria of quality.

3. To offer a list of apps by area of focus for children and adolescents with autism, in order to recommend their use according to the user's need.

4. To determine which are the most specialized and which the most multifaceted apps for education and intervention with children with autism. 


\section{Method}

\subsection{Sample}

For the analysis of the apps aimed at children and teenagers with autism, the Google Play Store search engine, available on mobile devices with the Android operating system, was taken as the starting point. The use of app stores for the development of research is a highly utilized resource in the international literature, and is relied upon by a range of researchers. Previous studies (Cayton et al., 2015; Comin, 2015; Crescenzi et al., 2019; Fage et al., 2018; García et al., 2016) have used app stores because they are the most popular and safest platforms for finding and downloading apps. Furthermore, the professionals and families of people with autism rely upon app stores to search for, download, install and later update these apps.

The sample comprised 155 free apps. The search terms "autismo", in Spanish, and "autism", in English, were used, thus covering the greatest number of apps in both languages. In the results section, each app appears with its name in the original language. The search was refined using rigorous pre-established exclusion criteria, which were: apps without any connection to autism; apps aimed at families or autism specialists but not specifically for people with this condition; apps with malfunctions or device incompatibilities; or apps repeated in both searches. Given the high number of apps for children with and without autism, we have only assessed those that include the keyword "autism" in their description.

\subsection{Instrument}

For the app evaluation, we used a "System of Indicators and Instrument for the Assessment and Selection of Apps for People with ASD", previously designed and validated by Gallardo-Montes et al. (2021c). The use of an indicator system makes it possible to evaluate in a tangible way the services offered by, in this case, the apps available on the Google Play Store. The aspects evaluated were governed by the criteria of what was necessary for an app aimed at children with autism. The proposed indicators were developed and analysed in depth from a psychopedagogical point of view, in accordance with previous studies focused on app evaluation (Araujo et al., 2007; Belloch, 2006; Cayton et al., 2015; Crescenzi \& Grané, 2016; Crescenzi et al., 2019; García-Rodríguez \& Gómez-Díaz, 2015; Fage et al., 2018; Larco et al., 2018). This instrument evaluated three dimensions of the apps (Table 3):

Table 3 Dimensions evaluated in the apps and indicators assessed

\begin{tabular}{ll}
\hline Dimension & Indicators \\
\hline D1: Design/Form & Availability, Ergonomics, Usability, Popularity, Accessibility. \\
D2: Content & Audio quality, Narration quality, Content, Notifications, Help/tutorials, Safety. \\
D3: Pedagogical aspects & Interactivity, Suitability of pace and learning, Feedback/assessment. \\
\hline
\end{tabular}


The indicator system was made up of 14 items, which were in turn divided into 46 sub-indicators, depending on the dimension. The instruments gave a final score, which allowed us to rank each app as: highly recommendable/Group 1 ( $\geq 37$ points); recommendable/Group 2 (36-23 points); or not recommendable/Group 3 ( $\leq 22$ points). The indicator system was positively assessed by a total of twelve judges with extensive experience in the education and technology field. The system obtained excellent Intraclass Correlation coefficients (ICC) $\left(\mathrm{ICC}_{\mathrm{D} 1}=.955, \mathrm{ICC}_{\mathrm{D} 2}=.973\right.$ and $\left.\mathrm{ICC}_{\mathrm{D} 3}=.966\right)$ and significant and strong Kendall's W inter-rater concordance (.757 and $1.00, \mathrm{p}<0.001)$. With a very high Cronbach's alpha coefficient $\left(\alpha_{\mathrm{D} 1}=.955\right.$, de $\alpha_{\mathrm{D} 2}=.973$ y $\alpha_{\mathrm{D} 3}=.966$ ), this was a valid and reliable instrument.

\subsection{Procedure}

In order to proceed to evaluate each app, we used a conventional smartphone connected through $\mathrm{AC} \mathrm{Wi}-\mathrm{Fi}$ at a speed of $600 \mathrm{Mb} / \mathrm{s}$, to prevent any alterations and to be able to make an assessment under equal conditions. Each app was installed on the device for two weeks and assessed progressively and thoroughly according to the indicator system, marking the presence or absence of each indicator and sub-indicator. Likewise, the area that each app worked on was indicated (communication, language, emotions, basic instrumental skills, executive functions and time management). The evaluation took place during the first quarter of 2019.

\subsection{Design and data analysis}

The study followed a quantitative design, taking the basic, non-experimental, simple descriptive and cross-sectional approach.

The analysis and evaluation of apps were recorded using Microsoft Office Excel 2016, indicating the area or areas they addressed (communication, language, emotions, basic instrumental skills, executive functions and time management) and writing 1 or 0 in each cell depending on the attainment or not, respectively, of the proposed indicator. Then the data were analysed with the SPSS statistical package version 25.0, with a margin of error of 5\% and a reliability level of $95 \%$. First, descriptive analysis (mean and standard deviation) was performed, as well as frequencies to find out the distribution by group, according to the quality of the apps evaluated, to determine which area(s) each app addressed, and to establish which area(s) was addressed the most and the least. Second, for the comparison between three groups of apps the univariate ANOVA - given the normality and homoskedasticity of the data - was used with the Bonferroni multiple comparisons test to define the groups in which significant differences were observed and Eta squared for estimations of the effect size. Third, to determine whether the quality of the apps depended on the areas they addressed, the chi-squared non-parametric test was used - given non-normality and homoskedasticity of the data. Finally, Pearson's correlation coefficient was calculated to establish the possible relations between the dimensions analysed, and between the different areas addressed by the apps. 


\section{Results}

The distribution of the apps by groups was as follows: $9.03 \%(n=14)$ attained the assessment for Group 1 (highly recommendable); 85.16\% $(n=132)$ for Group 2 (recommendable); and 5.81\% $(n=9)$ for Group 3 (not recommendable). Each app was examined to find out which area of work it developed.

Of the 155 apps analysed, only $1.94 \%(n=3)$ focused exclusively on one single area: "Nursery rhymes songs \& kids puzzle games free", "Relax melodies: sueño y yoga" and "The sensory processing game-autism \& spd free", which shows the lack of specialization of the apps as a whole. These three include content linked to leisure and entertainment and belong to Group 2, Recommendable apps. In contrast, most apps $(98.06 \%, n=152)$ work on more than one area simultaneously, although none of the apps dealt with all seven proposed areas simultaneously, suggesting the need for combinations. There were four apps $(2.58 \%)$ that tackled the highest number (six) of areas simultaneously: "LEA Lecto escritura para autismo", "Autastico" (both in Group 1), "SocialSkills for Autism Kloog 2" and "Tealite app" (both in Group 2). Eleven apps (7.10\%) exercised five areas at the same time, including "Otsimo", which obtained the highest overall score, while $20.65 \%(n=32)$ dealt with four areas at a time, including the high-scoring "\#Soyvisual". Finally, 44.52\% $(n=69)$ handled three areas; and $17.42 \%(n=27)$ involved two.

The area that was most present in the apps was communication (Table 4), appearing in 72 (46.45\%): ten belonging to Group 1 (Highly Recommendable), 58 apps to Group 2 (Recommendable), and only 4 apps to Group 3 (Not Recommendable). In the area of language (Table 4), 91 apps (58.71\%), of which 12 belong to Group 1 (Highly Recommendable), 75 apps to Group 2 (Recommendable), and 4 apps to Group 3 (Not Recommendable). Concerning the area of the emotions (Table 4), we found 24 apps (15.48\%); only six belonging to Group 1 (Highly Recommendable), 18 apps to Group 2 (Recommendable), and none to Group 3 (Not Recommendable). These three areas present a direct relation with social interaction and, therefore, with ToM, and so we have shown the results jointly (Table 4), given the need to promote these areas simultaneously.

With regard to time management (Table 5), $11.61 \%(n=18)$ of the apps worked on this area; just one app belonged to Group 1 (Highly Recommendable), 15 to Group 2 (Recommendable), and two to Group 3 (Not Recommendable).

In the area of instrumental skills (Table 6), we found 63 apps (40.65\%), of which eight were included in Group 1 (Highly Recommendable), 53 in Group 2 (Recommendable), and only two in Group 3 (Not Recommendable).

In the area of executive functions (Table 7), 148 apps were found (95.48\%), of which 14 belonged to Group 1 (Highly Recommendable), 128 to Group 2 (Recommendable), and six to Group 3 (Not Recommendable).

Lastly, in the area of leisure and entertainment (Table 8), 82 apps were found (52.90\%), of which eight were in Group 1 (Highly Recommendable), 72 in Group 2 (Recommendable), and only two in Group 3 (Not Recommendable).

We can therefore state that the area of executive functions features most in the apps $(n=148)$, followed by the area related to language $(n=91)$, then leisure 


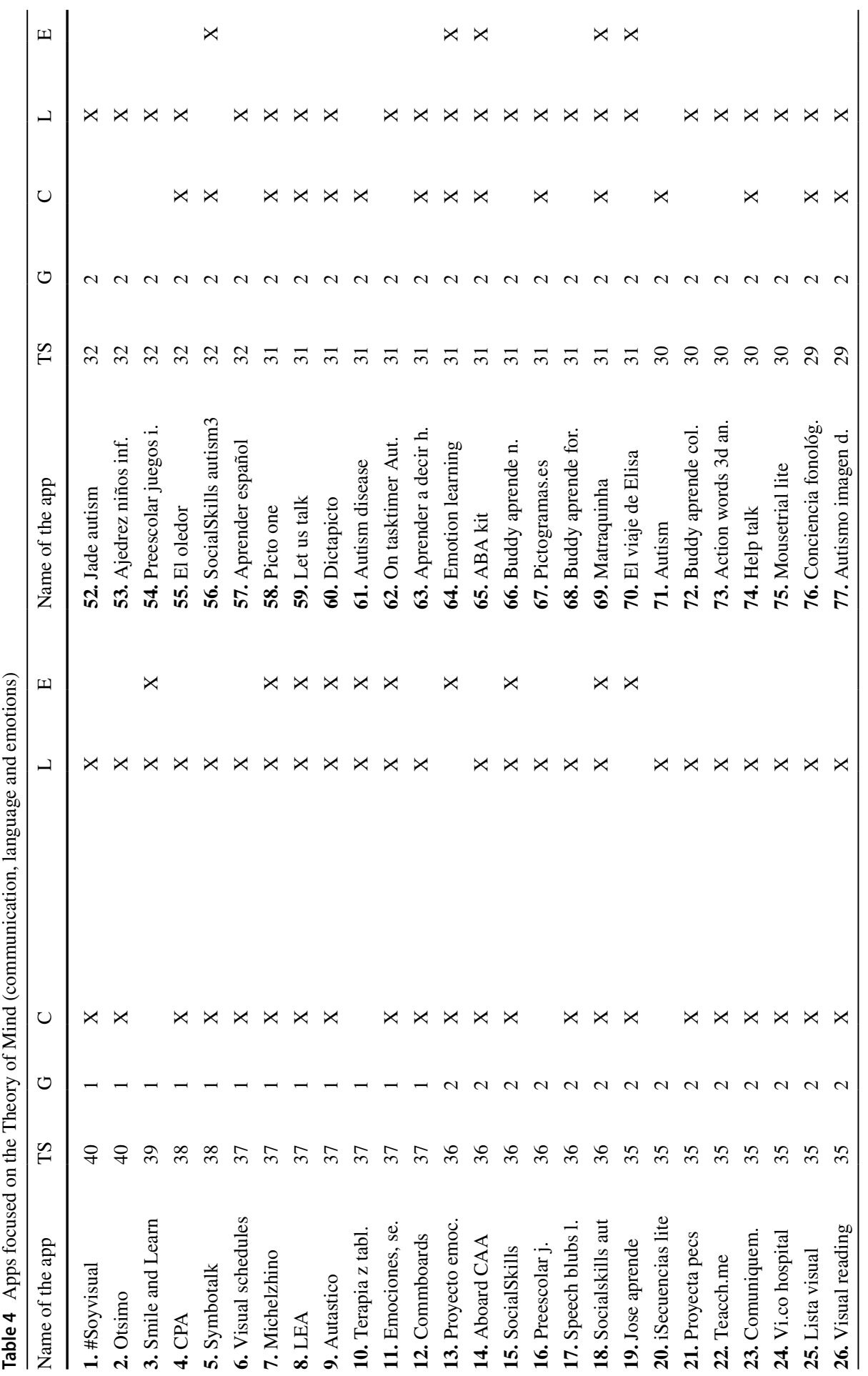




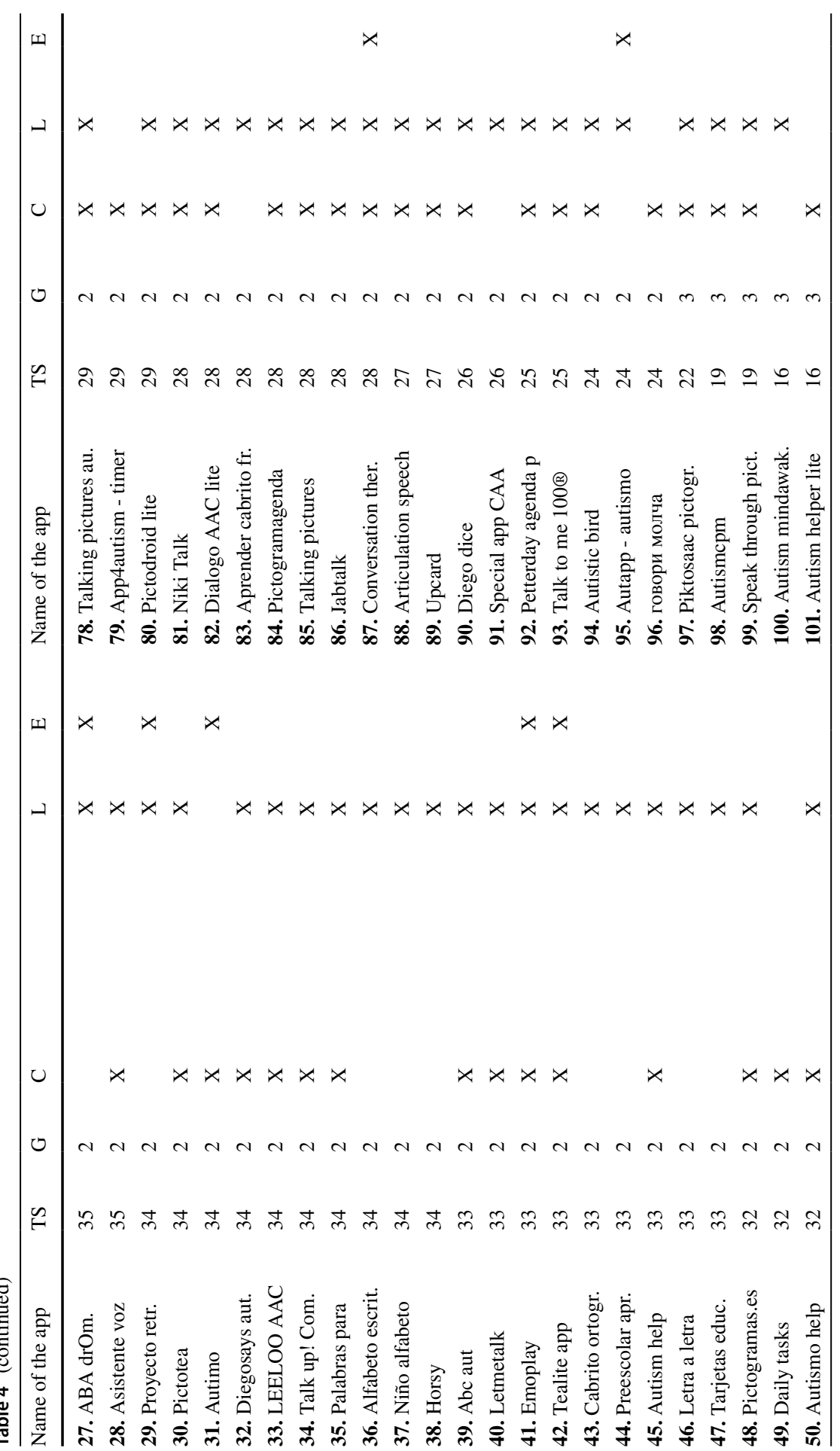




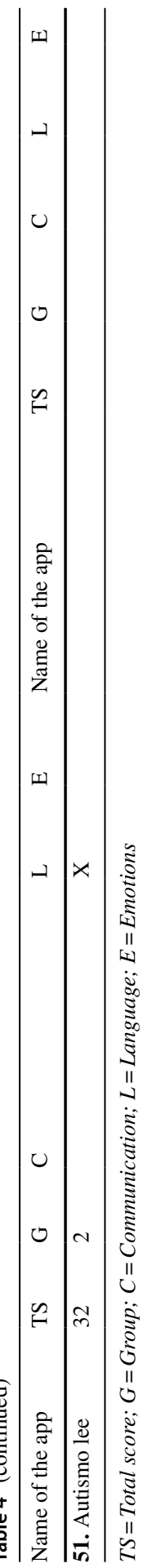

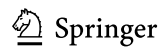


Table 5 Apps focused on time management

\begin{tabular}{llllrl}
\hline Name of the app & TS & G & Name of the app & TS & G \\
\hline 1. Visual schedules social stor. & 37 & 1 & 10. I'm on it focus timer & 29 & 2 \\
2. Lista visual - visual schedule & 35 & 2 & 11. Pictogramagenda & 28 & 2 \\
3. Tempus & 33 & 2 & 12. Conversation therapy lite & 28 & 2 \\
4. Social skills for autism 3 & 32 & 2 & 13. Upcard & 27 & 2 \\
5. Proyect@ habilidades & 31 & 2 & 14. Petterday agenda pictogramas & 25 & 2 \\
6. On tasktimer-utism timer & 31 & 2 & 15. Kids timer & 25 & 2 \\
7. Aprender a decir la hora & 31 & 2 & 16. Temporizador para niños timer & 25 & 2 \\
8. Children countdown timer & 29 & 2 & 17. In2token (Autism Token Boa.) & 20 & 3 \\
9. App4Autism timer, visual & 29 & 2 & 18. Visual time timer & 19 & 3 \\
\hline
\end{tabular}

TS = Total score; $G=$ Group

and entertainment in third $(n=82)$, communication in fourth $(n=72)$, and basic instrumental skills in fifth $(n=63)$. The areas dealt with the least were the emotions $(n=24)$ and time management $(n=18)$. From these frequencies, illustrated in Fig. 1, we can infer the needs of apps for users with ASD.

Additionally, the average quality of the apps can be affirmed as "Recommendable" $\left(x^{-}=2.03,85.16 \%\right)$ (Fig. 2). They did not attain the utmost quality of "Highly Recommendable" (only 9.03\%), but neither did they fall into the worst category, with only $5.81 \%$ forming the "Not Recommendable" group.

Differences were found regarding the above app rating by groups (1, 2 and $3)$, according to the ANOVA calculation $(F(2)=61.20)$, which produced significant differences $(p=.000)$ with a medium effect size $\left(\eta^{2}=.45\right)$. The differences were significant between all the groups, as the Bonferroni post-hoc tests showed ( $p=.000$ in all cases), showing heterogeneous subsets. Therefore, not all the apps are valid; users should choose them carefully.

Regarding the evaluation by dimension, only dimensions 2 (on "content") and 3 (on "pedagogical aspects") were matched, with a notable correlation, direct $(r=.57)$ and significant $(p=.000)$. In contrast, the relation of these dimensions with dimension 1 (on "design and form") was low ( $r_{\mathrm{D} 1-\mathrm{D} 2}=.21, p=.008$ and $\left.r_{\mathrm{D} 1-\mathrm{D} 3}=.17, p=.031\right)$.

The quality of the apps does not depend on the areas they work on, as demonstrated by the Chi-squared test $\left(\chi^{2}=5.56 ; p=.011\right)$, thus accepting the null hypothesis of no relationship between evaluations of the apps. In other words, apps of different quality can be found in every area, meaning that they should be evaluated before being employed in any particular area.

Furthermore, the apps analysed are clearly oriented toward certain areas. They are not comprehensive, thus adding to the aforementioned requirement the need for each user to have a clear work objective before arbitrarily using the apps. Indeed, of all the areas observed in the apps, only "communication" and "language" have a direct and significant relationship $(r=.52, p=.000)$, while "leisure" and "instrumental skills" are indirectly and significantly related $(r=.47$, $p=.000)$. 
Table 6 Apps focused on basic instrumental skills

\begin{tabular}{|c|c|c|c|c|c|}
\hline Name of the app & TS & $\mathrm{G}$ & Name of the app & TS & G \\
\hline 1. \#Soyvisual & 40 & 1 & 33. Tarjetas educativas español & 33 & 2 \\
\hline 2. Otsimo & 40 & 1 & 34. Autismo lee y escribe gratis & 32 & 2 \\
\hline 3. MITA & 39 & 1 & 35. Jade autism & 32 & 2 \\
\hline 4. Smile and Learn & 39 & 1 & 36. Niño juego de memoria alim. & 32 & 2 \\
\hline 5. LEA Lecto escritura & 37 & 1 & 37. Games for kids sea animals & 32 & 2 \\
\hline 6. Autastico & 37 & 1 & 38. Ajedrez niños infantil gratis & 32 & 2 \\
\hline 7. Juegos de niños para bebes & 37 & 1 & 39. Rompecabezas de niños din. & 32 & 2 \\
\hline 8. Terapia $\mathrm{z}$ tabletem & 37 & 1 & 40. Baby piano games \& music & 32 & 2 \\
\hline 9. SocialSkills Autism Kloog 2 & 36 & 2 & 41. Aprender español para niños & 32 & 2 \\
\hline 10. Preescolar juegos en españ. & 36 & 2 & 42. Aprender a decir la hora & 31 & 2 \\
\hline 11. Isecuencias lite & 35 & 2 & 43. Buddy aprende los numeros & 31 & 2 \\
\hline 12. Visual Reading educacion & 35 & 2 & 44. Buddy aprende las formas & 31 & 2 \\
\hline 13. Rompecabezas puzzingo & 35 & 2 & 45. Buddy aprende los colores & 30 & 2 \\
\hline 14. Niños de dibujo animado & 35 & 2 & 46. Autism speech sequencing & 30 & 2 \\
\hline 15. Animals puzzle for kids & 35 & 2 & 47. Kids puzzle car \& vechicles & 30 & 2 \\
\hline 16. Fotos de animales romp. & 35 & 2 & 48. Vehicles puzzle for kids & 30 & 2 \\
\hline 17. Vechicles puzzle for kids $\mathrm{p}$. & 35 & 2 & 49. MouseTrial Lite & 30 & 2 \\
\hline 18. ABA DrOmnibus for Par. & 35 & 2 & 50. Conciencia fonologica & 29 & 2 \\
\hline 19. Rompecabezas dinosaurios & 34 & 2 & 51. Autismo imagen discusión & 29 & 2 \\
\hline 20. Palabras para niños & 34 & 2 & 52. Autsim exit vn & 29 & 2 \\
\hline 21. Alfabeto escrito ABC 123 & 34 & 2 & 53. Romp. niños-habilidades $\mathrm{m}$. & 29 & 2 \\
\hline 22. Animal rompecabezas & 34 & 2 & 54. Aprender cabrito fruta & 28 & 2 \\
\hline 23. De suma y resta niños & 34 & 2 & 55. Games for kids wild animals & 28 & 2 \\
\hline 24. Niño alfabeto de aprendizaje & 34 & 2 & 56. Puzzles de animales para niños & 28 & 2 \\
\hline 25. Gratis niños juego de puzzle & 34 & 2 & 57. Games for kids retro cars & 27 & 2 \\
\hline 26. ABC Autismo & 33 & 2 & 58. Special app CAA & 26 & 2 \\
\hline 27. Tealite app & 33 & 2 & 59. Puzzles de frutas para niños & 25 & 2 \\
\hline 28. Niño conectar los puntos & 33 & 2 & 60. Focus & 25 & 2 \\
\hline 29. Cabrito juego de ortografia & 33 & 2 & 61. Games for kids modern cars & 23 & 2 \\
\hline 30. Preescolar aprende numeros & 33 & 2 & 62. Autismcpm & 19 & 3 \\
\hline 31. Dinosaurios rompecabezas & 33 & 2 & 63. Autism mindawakener & 16 & 3 \\
\hline 32. Letra a letra - deletrear & 33 & 2 & & & \\
\hline
\end{tabular}

$T S=$ Total score $;$ G Group

\section{Discussion and conclusions}

Smartphones and tablets are used frequently in the teaching-learning process, in therapy and in the family context of children and adolescents with autism. The use of electronic devices is an encouraging and attractive option for children with autism, due to the auditory and visual format that they often offer. Faced with the imminent technological proliferation of content addressed to minors with this 
Table 7 Apps focused on executive functions

\begin{tabular}{|c|c|c|c|c|c|}
\hline Name of the app & $\mathrm{TS}$ & $\mathrm{G}$ & Name of the app & $\mathrm{TS}$ & $\mathrm{G}$ \\
\hline 1. \#Soyvisual & 40 & 1 & 75. Social skills for autism 3 Kloogs & 32 & 2 \\
\hline 2. Otsimo & 40 & 1 & 76. Baby piano games \& music & 32 & 2 \\
\hline 3. MITA & 39 & 1 & 77. Aprender español para niños & 32 & 2 \\
\hline 4. Smile and Learn & 39 & 1 & 78. Picto one & 31 & 2 \\
\hline 5. $\mathrm{CPA}$ & 38 & 1 & 79. Let us talk & 31 & 2 \\
\hline 6. SymboTalk - AAC Talker & 38 & 1 & 80. Dictapicto & 31 & 2 \\
\hline 7. Visual schedules and social & 37 & 1 & 81. Autism disease & 31 & 2 \\
\hline 8. Michelzhino- emoçoes & 37 & 1 & 82. Proyect@ habilidades & 31 & 2 \\
\hline 9. LEA Lecto escritura & 37 & 1 & 83. On tasktimer-utism timer & 31 & 2 \\
\hline 10. Autastico & 37 & 1 & 84. Aprender a decir la hora & 31 & 2 \\
\hline 11. Juegos de niños para beb. & 37 & 1 & 85. Emotion learning for autistic & 31 & 2 \\
\hline 12. Terapia $\mathrm{z}$ tabletem & 37 & 1 & 86. ABA kit & 31 & 2 \\
\hline 13. Emociones, sentimientos & 37 & 1 & 87. Buddy aprende los numeros & 31 & 2 \\
\hline 14. CommBoards-gratis & 37 & 1 & 88. Pictogramas.es & 31 & 2 \\
\hline 15. Proyecto emociones & 36 & 2 & 89. Buddy aprende las formas & 31 & 2 \\
\hline 16. Aboard CAA & 36 & 2 & 90. Matraquinha & 31 & 2 \\
\hline 17. SocialSkills Autism 2 & 36 & 2 & 91. El viaje de Elisa & 31 & 2 \\
\hline 18. Preescolar juegos en esp. & 36 & 2 & 92. Autism & 30 & 2 \\
\hline 19. Quien es quien & 36 & 2 & 93. Buddy aprende los colores & 30 & 2 \\
\hline 20. Speech Blubs: Language & 36 & 2 & 94. Autism speech sequencing zapps & 30 & 2 \\
\hline 21. SocialSkills for Autism & 36 & 2 & 95. Kids puzzle car \& vechicles & 30 & 2 \\
\hline 22. Jose aprende & 35 & 2 & 96. Vehicles puzzle for kids & 30 & 2 \\
\hline 23. Isecuencias lite & 35 & 2 & 97. Action Words: 3D Animated & 30 & 2 \\
\hline 24. Proyecta PECS & 35 & 2 & 98. Help talk & 30 & 2 \\
\hline 25. Teacch.me & 35 & 2 & 99. MouseTrial Lite & 30 & 2 \\
\hline 26. Comuniquemonos & 35 & 2 & 100. Conciencia fonologica & 29 & 2 \\
\hline 27. Vi.co hospital lite & 35 & 2 & 101. Autismo imagen discusión & 29 & 2 \\
\hline 28. Lista visual - visual & 35 & 2 & 102. Autsim exit vn & 29 & 2 \\
\hline 29. Visual Reading educacion & 35 & 2 & 103. Talking pictures autism pc & 29 & 2 \\
\hline 30. Rompecabezas puzzingo & 35 & 2 & 104. Children countdown timer & 29 & 2 \\
\hline 31. Niños de dibujo animado & 35 & 2 & 105. Rompecabezas niños hab. & 29 & 2 \\
\hline 32. Animals puzzle for kids & 35 & 2 & 106. App4Autism - timer, visual & 29 & 2 \\
\hline 33. Fotos de animales romp. & 35 & 2 & 107. I'm on it: focus timer & 29 & 2 \\
\hline 34. Vechicles puzzle for kids & 35 & 2 & 108. Pictodroid lite & 29 & 2 \\
\hline 35. ABA DrOmnibus for Par. & 35 & 2 & 109. Preschool bus driver toddler & 29 & 2 \\
\hline 36. Asistente de voz AAC & 35 & 2 & 110. Niki Talk & 28 & 2 \\
\hline 37. Proyecto Retratos & 34 & 2 & 111. Dialogo AAC Lite Autism & 28 & 2 \\
\hline 38. Pictotea & 34 & 2 & 112. Aprendizaje sensorial de niños & 28 & 2 \\
\hline 39. Autimo & 34 & 2 & 113. Sonidos animales para niños & 28 & 2 \\
\hline 40. Diegosays autismo habla & 34 & 2 & 114. Piano para bebés: juego & 28 & 2 \\
\hline 41. Leeloo AAC - Autism & 34 & 2 & 115. Dibujos de arena - sand draw & 28 & 2 \\
\hline 42. Talk up! communicator & 34 & 2 & 116. Aprender cabrito fruta & 28 & 2 \\
\hline
\end{tabular}


Table 7 (continued)

\begin{tabular}{|c|c|c|c|c|c|}
\hline Name of the app & $\mathrm{TS}$ & G & Name of the app & TS & $\mathrm{G}$ \\
\hline 43. Rompecabezas de din. & 34 & 2 & 117. Games for kids wild animals & 28 & 2 \\
\hline 44. Palabras para niños & 34 & 2 & 118. Puzzles de animales para niños & 28 & 2 \\
\hline 45. Alfabeto escrito ABC 123 & 34 & 2 & 119. Sensory baby: games for babies & 28 & 2 \\
\hline 46. Animal rompecabezas b. & 34 & 2 & 120. Pictogramagenda & 28 & 2 \\
\hline 47. De suma y resta niños & 34 & 2 & 121. Talking pictures: autism, $\mathrm{cp}$ & 28 & 2 \\
\hline 48. Niño alfabeto & 34 & 2 & 122. Jabtalk & 28 & 2 \\
\hline 49. Horsy & 34 & 2 & 123. Conversation therapy lite & 28 & 2 \\
\hline 50. Gratis niños juego & 34 & 2 & 124. Kids tap and color (lite) & 28 & 2 \\
\hline 51. ABC Autismo & 33 & 2 & 125. Games for kids retro cars & 27 & 2 \\
\hline 52. Tempus & 33 & 2 & 126. Articulation speech theraphy & 27 & 2 \\
\hline 53. Letmetalk & 33 & 2 & 127. Upcard & 27 & 2 \\
\hline 54. Emoplay & 33 & 2 & 128. Special app CAA & 26 & 2 \\
\hline 55. Tealite app & 33 & 2 & 129. Petterday agenda pictogramas & 25 & 2 \\
\hline 56. Niño conectar los puntos & 33 & 2 & 130. Puzzles de frutas para niños & 25 & 2 \\
\hline 57. Cabrito juego de ortogr. & 33 & 2 & 131. Talk to me $100 ®$ Lite - Autism & 25 & 2 \\
\hline 58. Preescolar aprende num. & 33 & 2 & 132. Kids timer & 25 & 2 \\
\hline 59. Dinosaurios rompec. & 33 & 2 & 133. Focus & 25 & 2 \\
\hline 60. Autism help & 33 & 2 & 134. Temporizador para niños & 25 & 2 \\
\hline 61. Letra a letra - deletrear & 33 & 2 & 135. Comunicatea hus/surestea & 24 & 2 \\
\hline 62. Tarjetas educativas & 33 & 2 & 136. AutApp - Autismo & 24 & 2 \\
\hline 63. Pictogramas.es & 32 & 2 & 137. Говори молча: аутизм ДЦП & 24 & 2 \\
\hline 64. Daily tasks & 32 & 2 & 138. Autistic bird & 24 & 2 \\
\hline 65. Autismo help & 32 & 2 & 139. Autism sensory images & 24 & 2 \\
\hline 66. Autismo lee y escribe & 32 & 2 & 140. Games for kids modern cars & 23 & 2 \\
\hline 67. Jade autism & 32 & 2 & 141. Sensory & 23 & 2 \\
\hline 68. Puzzles para niños preesc. & 32 & 2 & 142. Pensar e facer & 22 & 3 \\
\hline 69. Niño juego de memoria & 32 & 2 & 143. Piktosaac pictogramas autismo & 22 & 3 \\
\hline 70. Games for kids sea & 32 & 2 & 144. In2token (Autism Token B.) & 20 & 3 \\
\hline 71. Ajedrez niños infantil & 32 & 2 & 145. Visual time timer & 19 & 3 \\
\hline 72. Preescolar juegos infant. & 32 & 2 & 146. Speak through Pictures-Autism & 19 & 3 \\
\hline 73. Rompecabezas de niños & 32 & 2 & 147. Autism mindawakener & 16 & 3 \\
\hline 74. El Oledor & 32 & 2 & 148. Autism helper lite & 16 & 3 \\
\hline
\end{tabular}

TS = Total Score; $G=$ Group

disorder, it was necessary to analyse what is really being offered to this group, since many professionals and families use devices of this kind on a daily basis and they depend upon the apps to foster the development of deficient skills (communication, emotions, time management, basic instrumental skills, executive functions and leisure/entertainment). 
Table 8 Apps focused on leisure and entertainment

\begin{tabular}{|c|c|c|c|c|c|}
\hline Name of the app & TS & $\mathrm{G}$ & Name of the app & TS & G \\
\hline 1. Otsimo & 40 & 1 & 42. El Oledor & 32 & 2 \\
\hline 2. MITA & 39 & 1 & 43. Social skills for autism 3 Kloogs & 32 & 2 \\
\hline 3. Smile and Learn & 39 & 1 & 44. Baby piano games \& music & 32 & 2 \\
\hline 4. LEA Lecto escritura & 37 & 1 & 45. Aprender español para niños Cog. & 32 & 2 \\
\hline 5. Autastico & 37 & 1 & 46. Buddy aprende los numeros & 31 & 2 \\
\hline 6. Juegos de niños bebes & 37 & 1 & 47. Buddy aprende las formas & 31 & 2 \\
\hline 7. Terapia $\mathrm{z}$ tabletem & 37 & 1 & 48. El viaje de Elisa & 31 & 2 \\
\hline 8. Emociones, sentimientos & 37 & 1 & 49. Buddy aprende los colores & 30 & 2 \\
\hline 9. Proyecto emociones & 36 & 2 & 50. Autism speech sequencing zapps & 30 & 2 \\
\hline 10. SocialSkills Autism 2 & 36 & 2 & 51. Kids puzzle car \& vechicles & 30 & 2 \\
\hline 11. Preescolar juegos esp. & 36 & 2 & 52. Vehicles puzzle for kids & 30 & 2 \\
\hline 12. Quien es quien & 36 & 2 & 53. Action Words: 3D Animated & 30 & 2 \\
\hline 13. Speech Blubs: Lang. & 36 & 2 & 54. MouseTrial Lite & 30 & 2 \\
\hline 14. SocialSkills for Autism & 36 & 2 & 55. Conciencia fonologica & 29 & 2 \\
\hline 15. Isecuencias lite & 35 & 2 & 56. Autismo imagen discusión & 29 & 2 \\
\hline 16. Rompecabezas puzz. & 35 & 2 & 57. Autsim exit vn & 29 & 2 \\
\hline 17. Niños de dibujo anim. & 35 & 2 & 58. Rompecabezas niños-habilidades & 29 & 2 \\
\hline 18. Animals puzzle & 35 & 2 & 59. Preschool bus driver toddler g. & 29 & 2 \\
\hline 19. Fotos de animales & 35 & 2 & 60. Relax melodies: sueño y yoga & 29 & 2 \\
\hline 20. Vechicles puzzle & 35 & 2 & 61. Aprendizaje sensorial de niños & 28 & 2 \\
\hline 21. ABA DrOmnibus par. & 35 & 2 & 62. Sonidos animales para niños & 28 & 2 \\
\hline 22. Rompecabezas de din & 34 & 2 & 63. Piano para bebés: juego & 28 & 2 \\
\hline 23. Alfabeto escrito ABC & 34 & 2 & 64. Dibujos de arena - sand draw & 28 & 2 \\
\hline 24. Animal rompecabezas & 34 & 2 & 65. Aprender cabrito fruta & 28 & 2 \\
\hline 25. Horsy & 34 & 2 & 66. Games for kids wild animals & 28 & 2 \\
\hline 26. Gratis niños juego & 34 & 2 & 67. Puzzles de animales para niños & 28 & 2 \\
\hline 27. Tealite app & 33 & 2 & 68. Sensory baby: games for babies & 28 & 2 \\
\hline 28. Niño conectar los puntos & 33 & 2 & 69. Kids tap and color (lite) & 28 & 2 \\
\hline 29. Cabrito juego de ortogr. & 33 & 2 & 70. Games for kids retro cars puzzles & 27 & 2 \\
\hline 30. Preescolar aprende num. & 33 & 2 & 71. The sensory processing game & 26 & 2 \\
\hline 31. Dinosaurios romp. & 33 & 2 & 72. Puzzles de frutas para niños & 25 & 2 \\
\hline 32. Autism help & 33 & 2 & 73. Focus & 25 & 2 \\
\hline 33. Tarjetas educativas & 33 & 2 & 74. AutApp - Autismo & 24 & 2 \\
\hline 34. Nursery rhymes songs & 33 & 2 & 75. Autistic bird & 24 & 2 \\
\hline 35. Pictogramas.es & 32 & 2 & 76. Autism sensory images & 24 & 2 \\
\hline 36. Puzzles para niños romp. & 32 & 2 & 77. Games for kids modern cars & 23 & 2 \\
\hline 37. Niño juego de memoria & 32 & 2 & 78. Sensory & 23 & 2 \\
\hline 38. Games for kids sea & 32 & 2 & 79. Fidget Stress buster & 23 & 2 \\
\hline 39. Ajedrez niños infantil & 32 & 2 & 80. Pensar e facer & 22 & 3 \\
\hline 40. Preescolar juegos infant. & 32 & 2 & 81._good_Fidget_Spinner_5891977 & 21 & 3 \\
\hline 41. Rompecabezas de niñ. & 32 & 2 & 82. Autism mindawakener & 16 & 3 \\
\hline
\end{tabular}

$T S=$ Total Score $;$ G Group 


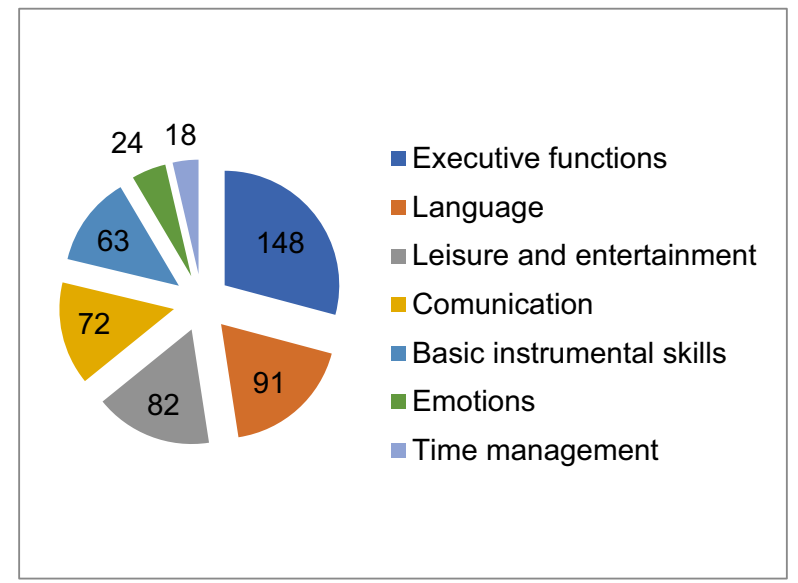

Fig. 1 Frequency of apps that present each of the areas worked on

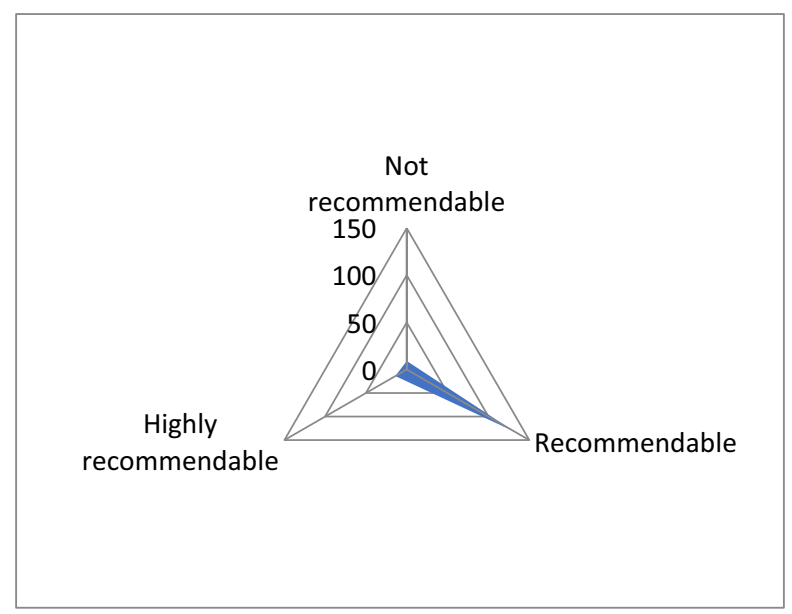

Fig. 2 Rating of the apps overall, assessed for autism

The evaluation of apps for children and adolescents with autism requires indepth analysis that examines content, design and pedagogical aspects, scrutinizing each app's peculiarities, which should be in keeping with the user's needs.

These days, accessing apps is relatively simple, but selecting which best fit the user's characteristics and needs is not, particularly for families. As Xanthopoulou et al. (2019) and Hanna et al. (2021) point out, no guidance exists for the selection and use of apps. This study will therefore facilitate this selection, since despite specifying a great variety of apps, it clearly shows which areas each one addresses and their overall quality, helping to make searching simpler and more intuitive, and increasing the possibility of finding the required content quickly. 
In general terms, the results obtained with this evaluation are encouraging, given the heterogeneity of the apps and the variety of different designs observed. Few apps have obtained an assessment of "not recommendable", since most apps were found in the "recommendable" group, with an average quality - as Hanna et al. (2021) also found in their study - but with potential for improvement in terms of quality, design, pedagogic aspects and content aimed at children and adolescents with autism. Furthermore, these results are in agreement with the findings of Dattolo and Luccio (2017) and Lian and Sunar (2021), which show that the design and content could be improved, as they were not wholly adapted to the needs and characteristics of people with ASD.

The study revealed the large variety of apps and the enormity of content they offer. Nonetheless, we can highlight several aspects. The apps that based their content on the development of executive functions were the most numerous, being present in 148 apps. This shows current knowledge on the need to promote this area from an early age and throughout the person with autism's development, which authors such as Guzmán et al. (2017) and Peirats et al. (2019) highlight in their studies. Of these 148 apps, only 8 have scientific evidence on the improvements produced in the area of the executive functions in users (Aguilar-Velázquez et al., 2020; Jiménez et al., 2017; Sung, 2018; Vyshedskiy et al., 2020): "MITA", "CPA" and "LEA Lecto escritura para autismo" from the "highly recommendable" group, and "SocialSkills for Autism Kloog 2", "LetMeTalk", "Autism help", "Pictodroid lite" and "Niki Talk" from the "recommendable" group. Studies such as that by Teixeira and Cunha (2019) also show progress in the increase in attention and behaviour through the use of the app "123 Autismo", which was not included in this study.

The apps linked to ToM were highly represented $(n=101)$, showing an average quality, whereas in the study by Crespo and Martín (2018) they were considered optimal for children with autism. Along the same lines, Adamu et al. (2019) show that the apps addressing communication had interfaces that were tied to the child's characteristics. Previous studies indicate progress in the prerequisites of language, communicative intent and behaviour through the use of the apps " $C P A$ " and " $L E A$ Lecto escritura para autismo" (both "highly recommendable"), and "LetMeTalk", "Autism help" "Pictodroid Lite" and "Niki Talk" (from the "recommendable" group) (Aguilar-Velázquez et al., 2020; Jiménez et al., 2017; Sung, 2018). LázaroCantabrana et al. (2019) show improvements in the understanding of information, and capacity for expression and communication through the app "SOS TEA", which was not analysed in this study. However, the apps that focused on the development of emotions were not predominant in the app catalogue. They mostly fell into the "recommendable" group, and none were "not recommendable". The imbalance between these apps and the rest was striking. Despite this, the apps available did not obtain bad scores or evaluations. Indeed, authors such as Matey (2017) and González et al. (2016) highlight the encouraging results from the use of mobile apps linked to the emotional sphere.

Likewise, with time management, wherein most of the apps addressing it attained a recommendable rating. It seems curious that aspects connected to ToM (Premack \& Woodruff, 1978), such as the emotions and time management, routine establishment and task organization, appear so infrequently compared to the rest of the app 
catalogue. These areas should be fostered from an early age, given that they are necessary for social interaction itself. Although their number is few, it is encouraging that these apps obtained a good assessment, and can be used effectively and successfully by families, teachers and autism specialists.

The development of basic instrumental skills was included in 63 of the apps assessed, and this was one of the aspects utilized in previous studies, with benefits gained from their use. Examples of these include "MITA", rated as "highly recommendable" (Vyshedskiy et al. 2020); "LEA Lecto escritura para autismo", also "highly recommendable" (Aguilar-Velázquez et al., 2020); and "SocialSkills for Autism Kloog 2", assessed as "recommendable" (Sung, 2018). Other studies, such as those by Teixeira and Cunha (2019) with the app "123 Autism", Sweidan et al. (2019) with "Autistic Innovate Assistant (AIA)", and Lázaro-Cantabrana et al. (2019) with the app "SOS TEA" (not evaluated here), also show successful results in the development of the basic instrumental skills, with progress in mathematical, linguistic and communicative skills.

Regarding the apps for leisure and entertainment, we observe an increase in their presence in the digital app market, in contrast to the study by Crespo and Martín (2018), who report their limited presence and lack of representation, and call for research and development in this area. However, we have not found any scientific evidence on the use of apps for the enjoyment of leisure and free time in children with autism.

Most apps did not focus on one single area, as in the study by Crespo and Martín (2018), making them more functional and multifaceted, but, consequently, not specialized. The two apps with the highest ratings, "\#Soyvisual" and "Otsimo", work, respectively, on four and five areas simultaneously, which means that with a single app different areas are addressed, with content, design and pedagogical approach of quality. Other apps, also high-scoring, included even more areas in their content, such as "LEA Lecto escritura para autismo" and "Autastico" (both rated as highly recommendable), and "SocialSkills for Autism Kloog 2" o "Tealite app" (both recommendable). The quality of the apps did not depend on the areas they worked on, and so we must not assume that all apps are equal; not all apps are valid and they should be chosen with care. The use made of the apps will depend on the aims set by teachers, specialists, and families, as well as on the activity, the content sought and the characteristics of the users.

As was to be expected, the apps that revolve around the area of communication and language revealed a direct relationship. These areas have a strong connection in human interaction, since even though communication encompasses a broad spectrum of expressions (eye contact, gestures, etc.), the presence of a functional language gives it value and meaning. These aspects can be observed in Jiménez et al. (2017): after using mobile devices for this purpose, the communicative processes and language production increased. As has been seen, many apps worked on both topics jointly, and different forms of task and content can be found, depending on the developmental stage of the child or the context in which learning is managed and undertaken.

The purpose of any proper intervention should be aimed at the comprehensive development of the person with autism. Thus, as has been evident throughout the 
study, the apps are set up as a constantly changing and updated resource, according to the needs and requirements of the educational system and the practices involved in psychopedagogical intervention. In turn, given the active participation of the family as essential actors in the raising and development of the child with autism, ICT resources such as apps are available to everyone who wishes to make use of them. Times have changed, and with them the way that families help and provide resources to their children. The content of apps not only aims to provide accessibility to people with functional diversity, but also include tutorials and instructions for family members, with intuitive and easy-to-manage designs. However, in the apps specifically for children with autism, these tools were only found in a minority (written tutorials: 24.5\%, $n=38$; audio tutorials: $9.03 \%, n=14$ ). This lack was also noted by Cayton et al. (2015) and Hanna et al. (2021), the latter stating that contents need to be presented to families in a clear way in order for the orientation and guided use with family members with ASD to be successful.

It was clear, from the analysis undertaken, that when an app is being designed for children with autism, the specialist teams (educators and programmers) need to work together from the beginning of the process to agree on the specific requirements of this group and the options an app can offer, and, when possible, to seek input from the children and teenagers with autism themselves (Fletcher-Watson et al., 2016), or at least with their carers, to ensure that the content is appropriate. As we have seen, there was little relation between the "design/form" dimension and the "content" and "pedagogical aspects" dimensions. This lack of relation could cause dissatisfaction for everyone involved, but particularly among users. In order to overcome difficulties and obstacles, consideration should be given to the Web Content Accessibility Guidelines (WCAG) proposed by the World Wide Web, known as W3C (Lawton, 2005). Close collaboration between teams is also essential to produce better app functionality. Previous studies, such as Sofian et al. (2016, 2018), Sanromà-Giménez et al. (2021) and Gallardo-Montes et al. (2021b), argue precisely for the attention that should be given to the criteria linked to an app's appearance, its usability, accessibility and its pedagogical aspects. The criteria considered in the three dimensions mentioned above could serve not only for their analysis but also as basic guidelines for app creation. Web tools could even be created for prior, online evaluation to see whether an app meets the preestablished dimensions and criteria. This type of tool already exists for other dimensions, such as for assessing website accessibility for people with visual impairment and other specific characteristics, as provided by the Siteimprove Accessibility Checker. Ultimately, the aim is to lessen the barriers to learning and participation faced by some people with functional diversity.

As well as the suitable creation of apps, in terms of their specific use, we recommend that guidance on how to select and use apps be included in both initial and lifelong training in pedagogical-didactic and digital competences, in accordance with criteria such as the above, for teachers, educators and other professionals who work with children with autism. Neither should it be forgotten that close collaboration between schools and families is not only an advantage but a necessity (Xanthopoulou et al., 2019). Establishing user profiles and also profiles for carers or supervisors (teacher, educator, family members, etc.) could foster a more personalized use that is tailored to the needs of the child with autism. We also advise families and 
professionals to monitor the apps before offering them to children (Xanthopoulou et al., 2019). And, of course, it is very important that consideration be given when selecting apps for use with children and adolescents with autism to those that are based on scientific principles and/or supported by empirical research (Allen et al., 2016). This is still a hard task, as most apps have not yet been backed by scientific evidence on their validity and efficacy (Crespo \& Martín, 2018). It is therefore crucial for there to be collaboration between researchers and teaching and/or multiprofessional teams that use the apps in their work with children with autism. This will facilitate the study and dissemination of their experience and findings, with an emphasis not only on the benefits obtained but also on the difficulties encountered and the potential options to overcome them.

A possible limitation of this study is that there are still few studies on the evaluation of apps for children with autism. Furthermore, in some of the previous studies, they evaluate apps other than those analysed here - the criteria for evaluation are different or the studies are systematic reviews, which makes it difficult to compare results. Yet this also means that this study fills a gap in the research. Another limitation of the study concerns the exclusion of apps developed for other operating systems (iOS, Harmony, etc.), as well as apps that require purchase, since our assessment focuses exclusively on free apps for Android available on the Google Play Store.

In terms of future research, it would be interesting to find out what use both professionals who work with children with ASD and families are actually making of apps. This will make it possible to know whether the best apps are really the most used, if they meet users' needs and the stipulated aims, as well as whether they prove to be intuitive to use (as one would hope), or whether, in contrast, they prove difficult. It would also be worthwhile to assess to what degree an app proves recommendable if it is analysed from the perspective of the quality of the area it addresses.

This study aims to be a novel tool to guide specialists, teachers and families in choosing the best apps for children with autism, according to the content to address and the characteristics of the user. It also sets out to indicate what aspects need improvement in app design, which programmers could bear in mind to enhance accessibility and functionality. Together, this would help apps to become an optimal resource for children with autism.

Availability of data and material There are no data sets or other materials to supply.

Authors' contributions Conceptualization: Carmen del Pilar Gallardo Montes, María Jesús Caurcel Cara, Antonio Rodríguez Fuentes; Data curation: Carmen del Pilar Gallardo Montes, María Jesús Caurcel Cara, Antonio Rodríguez Fuentes; Formal Analysis: Carmen del Pilar Gallardo Montes, María Jesús Caurcel Cara, Antonio Rodríguez Fuentes; Funding acquisition: Carmen del Pilar Gallardo Montes; Investigation: Carmen del Pilar Gallardo Montes, María Jesús Caurcel Cara, Antonio Rodríguez Fuentes; Methodology: Carmen del Pilar Gallardo Montes, María Jesús Caurcel Cara, Antonio Rodríguez Fuentes; Project administration: Carmen del Pilar Gallardo Montes, María Jesús Caurcel Cara, Antonio Rodríguez Fuentes; Resources: Carmen del Pilar Gallardo Montes, María Jesús Caurcel Cara, Antonio Rodríguez Fuentes; Software: Carmen del Pilar Gallardo Montes, María Jesús Caurcel Cara, Antonio Rodríguez Fuentes; Supervision: María Jesús Caurcel Cara, Antonio Rodríguez Fuentes; Validation: Carmen del Pilar Gallardo Montes, María Jesús Caurcel Cara, Antonio Rodríguez Fuentes; Visualization: Carmen del Pilar Gallardo 
Montes, María Jesús Caurcel Cara, Antonio Rodríguez Fuentes; Writing - original draft: Carmen del Pilar Gallardo Montes, María Jesús Caurcel Cara, Antonio Rodríguez Fuentes; Writing - review \& editing: Carmen del Pilar Gallardo Montes, María Jesús Caurcel Cara, Antonio Rodríguez Fuentes.

Funding This work was supported by the University of Granada and the Spanish Ministry of Education, Innovation and Universities (aid for university teacher training [FPU19/00026]). Funding for open access charge: University of Granada / CBUA.

Code availability Not applicable.

\section{Declarations}

Ethics approval Not aplicable.

Consent to participate Not aplicable.

Consent for publication The authors consent to the publication of the results described in the article.

Competing interests The authors have no relevant financial or non-financial interests to disclose.

Open Access This article is licensed under a Creative Commons Attribution 4.0 International License, which permits use, sharing, adaptation, distribution and reproduction in any medium or format, as long as you give appropriate credit to the original author(s) and the source, provide a link to the Creative Commons licence, and indicate if changes were made. The images or other third party material in this article are included in the article's Creative Commons licence, unless indicated otherwise in a credit line to the material. If material is not included in the article's Creative Commons licence and your intended use is not permitted by statutory regulation or exceeds the permitted use, you will need to obtain permission directly from the copyright holder. To view a copy of this licence, visit http://creativecommons.org/licen ses/by/4.0/.

\section{References}

Adamu, A. S., Abdullahi, S. E., \& Aminu, R. K. (2019, December). A survey on software applications use in therapy for autistic children [conference session]. In 15th international conference on electronics computer and computation. Nigeria. https://doi.org/10.1109/ICECCO48375.2019. 9043237

Allen, M. L., Hartley, C., \& Cain, K. (2016). iPads and the use of "apps" by children with autism Spectrum disorder: Do they promote learning? Frontiers in Psychology, 7, 1305. https://doi.org/10.3389/ fpsyg.2016.01305

Aguilar-Velázquez, R., García-Hernández, L. I, Corla-Ávila, G., Toledo-Cárdenas, M.R., HerreraCovarrubias, D., Hernández-Aguilar, M.E., \& Manzo-Denes, J. (2020) LEA: aplicación web para estimular la lectoescritura en niños con autismo. Eduscientia. Divulgación de la ciencia educativa, 6, 46-63. http://eduscientia.com/index.php/journal/article/view/74. Accessed 30 Oct 2020.

American Psychiatry Association (2014). Manual de diagnóstico y estadístico de los trastornos mentales (DSM-V), $5^{\text {a }}$ edición. Editorial Médica Panamericana.

Anzaldo, M., \& Cruz Ruiz, L. P. (2019). Capacidades científicas en el Trastorno del Espectro Autista en México: reflexiones desde el vínculo entre ciencia, tecnología e innovación y políticas sociales. Ciencia y Sociedad, 44(1), 13-26. https://doi.org/10.22206/cys.2019.v44i1

Araujo, D., Bermúdez, J., \& Nuñez, S. (2007). Criterios de evaluación en aplicaciones multimedia en entornos de educación y formación a distancia. Revista Electrónica de Estudios Telemáticos, 6(2), 1-17. https://bit.ly/3mYOS8y. Accessed 30 Oct 2020. 
Autismo Diario. (2017). Enseñando a leer y escribir a niños con autismo. Retrieved from https://bit.ly/ 2UJPvHk. Accessed 14 Apr 2021.

Baixauli, I., Roselló, B., Berenguer, C., Colomer, C., \& Grau, M.D. (2017). Intervenciones para promover la comunicación social en niños con trastornos del espectro autista. Revista de Neurología, 64(1), 39-44. https://doi.org/10.33588/rn.64S01.2017013.

Belloch, C. (2006). Evaluación de las aplicaciones multimedia: criterios de calidad. Unidad de Tecnología Educativa, University of Valencia. https://www.uv.es/bellochc/pdf/pwtic4.pdf. Accessed 30 Oct 2020.

Bondioli, M., Buzzi, M. C., Buzzi, M., Giuca, M. R., Pardossi, F., Pelagatti, S., Semuci, V., Senette, C., Uscidda, F., \& Vagelli, B. (2018). MyDentist: Making children with autism familiar with dental care. Adv. Intell. Syst. Comput., 806, 365-372. https://doi.org/10.1007/978-3-030-01746-0_43

Boster, J. B., \& McCarthy, J. W. (2018). Designing augmentative and alternative communication applications: The results of focus groups with speech-language pathologists and parents of children with autism spectrum disorder. Disability and Rehabilitation: Assistive Technology, 13(4), 353-365. https://doi.org/10.1080/17483107.2017.1324526

Cappe, E., Bolduc, M., Poirier, N., Popa-Roch, M. A., \& Boujut, E. (2017). Teaching students with autism Spectrum disorder across various educational settings: The factors involved in burnout. Teaching and Teacher Education, 67, 498-508. https://doi.org/10.1016/j.tate.2017.07.014

Castro, M., \& Mallón, O. (2019). La Tablet en la escuela: Revisión bibliográfica en Scopus. Hamut'ay, 6(1), 124-139 https://doi.org/10.21503/hamu.v6i1.1579

Cayton, G. A., Feng, G., \& Pan, X. (2015). Tablet-based math assessment: What can we learn from math apps? Educational Technology \& Society, 18(2), 3-20. https://bit.ly/3BvPqHp. Accessed 30 Oct 2020.

CeRMi, Comunidad de Madrid (2018). Ocio y Tiempo libre de las Personas con discapacidad y sus familias en la ciudad de Madrid. CeRMi.

Comin, S. (2015). Apps e infancia. Estudio de las apps educativas para dispositivos móviles orientadas a la enseñanza infantil. (Master's Thesis). National University of Distance Education, Spain. https://bit.ly/3xSuadv. Accessed 30 Oct 2020.

Crescenzi, L., \& Grané, M. (2016). Análisis del diseño interactivo de las mejores apps educativas para niños de cero a ocho años. Comunicar, 24(46), 77-85. https://doi.org/10.3916/C46-2016-08

Crescenzi, L., Valente, R., \& Suárez, R. (2019). Aplicaciones educativas seguras e inclusivas: La protección digital desde una perspectiva ética y crítica. Comunicar, 27(61), 93-102. https://doi.org/ 10.3916/C61-2019-08

Crespo, F., \& Martín, E. (2018). Applications for mobile devices focused on support for autism spectrum disorder population and / or people in their immediate environment in their daily lives: A systematic and practical review from a Spanish-speaking perspective. Human-computer interaction, 1-16. https://arxiv.org/abs/1806.01041. Accessed 1 Sept 2021.

Dattolo, A., \& Luccio, F.L. (2017, November). A review of websites and mobile applications for people with autism Spectrum disorders: Towards shared guidelines [conference session]. International conference on smart objects and technologies for social good. Pisa, Italy. https://doi.org/ 10.1007/978-3-319-61949-1_28

David, D.O., Costescu, C.A., Matu, S, Szentagotai, A., \& Dobrean, A. (2019). Effects of a robotenhanced intervention for children with ASD on teaching turn-taking skills. Journal of educational computing research, 58(1), 29-62. https://doi.org/10.1177/0735633119830344.

De Castro, M., Neto, L., Laudelino, A., Cortez, S.M., \& García, L.S. (2018). El fenómeno del lenguaje de la ecolalia en los trastornos del espectro autista y el derecho y los desafíos de la educación inclusiva. UCV HACER, 7(2), 21-25. https://doi.org/10.18050/ucv-hacer.v7i2.1440.

Fage, C., Consel, C. Y., Balland, E., Etchegoyhen, K., Amestoy, A., Bouvard, M., \& Sauzéon, H. (2018). Tablet apps to support first school inclusion of children with autism Spectrum disorders (ASD) in mainstream classrooms: A pilot study. Frontiers in Psychology, 9, 1-16. https://doi. org/10.3389/fpsyg.2018.02020

Fletcher-Watson, S., Pain, H., Hammond, S., Humphry, A., \& McConachie, H. (2016). Designing for young children with autism spectrum disorder: A case study of an iPad app. International Journal of Child-Computer Interaction, 7, 1-14. https://doi.org/10.1016/j.ijcci.2016.03.002

Fortea, M. S., Escandell, M. O., \& Castro, J. J. (2013). ¿Cuántas personas con autismo hay? Una revisión teórica. International Journal of Developmental and Educational Psychology, 1(1), 769-786. https://bit.ly/3t5ZiED. Accessed 30 Oct 2020. 
Gallardo-Montes, C. P., Caurcel, M. J., \& Rodríguez, A. (2021c). Diseño de un sistema de indicadores para la evaluación y selección de aplicaciones para personas con Trastorno del Espectro Autista. Revista Eletrónica EDUCARE, 25(3), 1-24. https://doi.org/10.15359/ree.25-3.18.

Gallardo-Montes, C. P., Caurcel, M. J., Crisol, E., \& Jarque, S. (2021a). Assessment of apps aimed at developing basic instrumental skills in autistic children and teenagers. Mathematics, 9(9), 1032. https://doi.org/10.3390/math9091032

Gallardo-Montes, C. P., Rodríguez, A., \& Caurcel, M. J. (2021b). Apps for people with autism: Assessment, classification and ranking of the best. Technology in Society, 64, 101474. https:// doi.org/10.1016/j.techsoc.2020.101474

García-Rodríguez, A., \& Gómez-Díaz, R. (2015). Las demasiadas aplicaciones: parámetros e indicadores para seleccionar las TopAPP de lectura para niños. Anales de Documentación, 18(2), 1-17. https://doi.org/10.6018/analesdoc.18.2.227071

García, S., Garrote, D., \& Jiménez, S. (2016). Uso de las TIC en el Trastorno de Espectro Autista: aplicaciones. EDMETIC, Revista de Educación Mediática y TIC, 5(2), 134-157. https://helvia. uco.es/xmlui/handle/10396/14211. Accessed 30 Oct 2020.

Goldstein, S., Naglieri, J. A., Princiotta, D., \& Otero, T. M. (2014). Introducción: una historia de funcionamiento ejecutivo como construcción teórica y clínica. In S. Goldstein y J. A. Naglieri (Eds.), Manual de Funcionamiento Ejecutivo (pp. 3-12). Springer.

González, J.L., Montero, C., Batanero, M., Montero, E., de la Fuente, M.L., \& González, L. (2016). Una "inclusiva" mirada de la tecnología en nuestro colegio. Trabajando con una mirada especial: TEA y TIC en nuestro colegio. Revista Padres y Maestros, 385, 41-48. https://doi.org/10.14422/pym.i365. y2016.006.

Guzmán, G., Putrino, N., Martínez, F., \& Quiroz, N. (2017). Nuevas tecnologías: Puentes de comunicación en el trastorno del espectro autista (TEA). Terapia Psicológica, 35(3), 247-258. https://doi. org/10.4067/S0718-48082017000300247

Hanna, N., Lydon, H., Holloway, J., Barry, L., \& Walsh, E. (2021). Apps to teach social skills to individuals with autism Spectrum disorder: A review of the embedded behaviour change procedures. Review Journal of Autism and Developmental Disorders. https://doi.org/10.1007/s40489-021-00271-w

Haque, M.M., Rabbani, M., Dipal, D.D., Zarif, I.I., Iqbal, A., Akhter, S., Parveen, S., Rasel, M., Rabbani, G., Alam, F., Soron, T.R., Ahmed, S.I., \& Ahamed, S.I. (2021). Grant report on mCARE: Mobilebased care for children with autism Spectrum disorder (ASD) for low- and middle-income countries (LMICs). Journal of psychiatry and brain science, 6. https://doi.org/10.20900/jpbs.20210004.

Hernández, M. E., \& Sosa, M. E. (2018). Uso de Tecnologías de Información y Comunicación (TIC) en inclusión escolar de estudiantes con Trastornos del Espectro Autista (TEA). Contextos: Estudios de humanidades y ciencias sociales, 41, 1-10. https://bit.ly/3t74HLP. Accessed 30 Oct 2020.

Hussain, A., Mkpojiogu, E. O. C., \& Okoroafor, P. C. (2021). Assisting children with autism Spectrum disorder with educational mobile apps to acquire language and communication skills: A review. International Journal of Interactive Mobile Technologies, 15(6), 161-170. https://doi.org/10.3991/ ijim.v15i06.20621

Íñiguez, T. (2013). Aprendizaje instrumental accesible para todos y todas. ESCUELA, Comunidades de aprendizaje, 5, 1-8. https://bit.ly/3wEugUu. Accessed 30 Oct 2020.

Jiménez, M. D., Serrano, J. L., \& Prendes, M. P. (2017). Estudio de caso de la influencia del aprendizaje electrónico móvil en el desarrollo de la comunicación y el lenguaje con un niño con TEA. EDUCAR, 53(2), 419-443. https://doi.org/10.5565/rev/educar.782

Kucirkova, N. (2019). Children's agency by design: Design parameters for personalization in story-making apps. International Journal of Child-Computer Interaction, 21, 112-120. https://doi.org/10. 1016/j.ijcci.2019.06.003

Larco, A., Yáñez, C., Montenegro, C., \& Luján-Mora, S. (2018). Moving beyond limitations: Evaluating the quality of android apps in Spanish for people with disability. Adv. Intell. Syst. Comput., 721, 640-649. https://doi.org/10.1007/978-3-319-73450-7_61

Lázaro-Cantabrana, J.L., Sanromà, M., Molero, T., Queralt, M., y Llop, M. (2019). Diseño de una aplicación móvil para la seguridad de las personas con trastorno del espectro autista: SOS TEA. Revista de Educación Inclusiva, 12(1), 139-160. https://bit.ly/3sM9CBz. Accessed 1 Sept 2020.

Lawton, S. (2005). WAI: Web accessibility initiative. W3C (world wide web consortium). https://www. w3c.es/Traducciones/es/WAI/intro/accessibility. Accessed 1 Sept 2020.

Leech, T., Dorstyn, D., Taylor, A., \& Li, W. (2021). Mental health apps for adolescents and young adults: A systematic review of randomised controlled trials. Children and Youth Services Review, 127, 106073. https://doi.org/10.1016/j.childyouth.2021.106073 
Lian, X., \& Sunar, M. S. (2021). Mobile augmented reality Technologies for Autism Spectrum Disorder interventions: A systematic literature review. Applied Sciences, 11(10), 4550. https://doi.org/10. 3390/app11104550

Lorenzo, G., Lledó, A., \& Pérez-Vázquez, E. (2021). Action protocol for the use of robotics in students with autism Spectrum Disoders: A systematic-review. Education and Information Technologies, 26, 4111-4126. https://doi.org/10.1007/s10639-021-10464-9

Lozano, J., Castillo, I.S., García, C., \& Motos, E. (2013a). El desarrollo de habilidades emocionales y sociales en alumnado con trastorno del espectro autista: una investigación colaborativa en Educación Infantil y Primaria. Didáctica, innovación y multimedia, 26, 1-11. https://ddd.uab.cat/record/ 112701. Accessed 30 Oct 2020.

Lozano, J., \& Merino, S. (2015). Utilización de las TICs para desarrollar las habilidades emocionales en alumnado con tea desde la colaboración escuela-familia-universidad: una experiencia en un aula abierta específica. DIM Revista, 11(31), 1-16. https://bit.ly/3ju9O5j. Accessed 30 Oct 2020.

Lozano, J., Ballesta, F., Cerezo, M. C., \& Alcaraz, S. (2013). Las Tecnologías de la Información y la Comunicación (TIC) en el proceso de enseñanza y aprendizaje del alumnado con Trastorno del Espectro Autista (TEA). Revista Fuentes, 14, 193-208 https://n9.cl/fohuv. Accessed 30 Oct 2020.

Málaga, I., Blanco, R., Hedrera, A., Álvarez, N., Oreña, V.A., \& Baeza, M. (2019). Prevalencia de los Trastornos del Espectro Autista en niños en Estados Unidos, Europa y España: coincidencias y discrepancias. Medicina Buenos Aires, 79(1), 4-9. https://bit.ly/3BslATW

March, I., Montagut, M., Pastor, G., \& Fernández, M.I. (2018). Intervención en habilidades sociales de los niños con Trastorno del Espectro Autista: una revisión bibliográfica. Papeles del Psicólogo, 39(2), 140-149. https://doi.org/10.23923/pap.psicol2018.2859.

Martín, O., Daza, M.T., Santiago, E., Garrido, P., \& Ruiz, P. (2020). Evaluación Neuropsicológica de las Funciones Ejecutivas en pacientes con Trastorno Mental Grave. Know and Share Psychology, 1(1), 7-21. https://doi.org/10.25115/kasp.v1i1.3065

Mazza, M., Mariano, M., Peretti, S., Masedu, F., Chiara, M., \& Valenti, M. (2017). The role of theory of mind on social information processing in children with autism spectrum disorders: A mediation analysis. Journal of autism and developmental disorders, 47(59), 1369-1379. https://doi.org/10. 1007/s10803-017-3069-5.

Matey, A. (2017). Contribución de las TIC al desarrollo de la competencia emocional en el Trastorno del Espectro Autista. Una intervención en caso único. (Master's Thesis). University of Jaume I, Castellón de la Plana, Spain.

Orellana, L. (2016). Actividades en las aulas de Comunicación y Lenguaje con niños/as con Trastorno del Espectro del Autismo. Una investigación narrativa. ArtsEduca, 13, 82-99. https://bit.ly/3gMchq7. Accessed 30 Oct 2020.

Pedreño, C., Pousa, E., Navarro, J., Pámias, M., \& Obiols, J. (2017). Exploring the components of advanced theory of mind in autism spectrum disorder. Journal of Autism and Developmental Disorders, 47(8), 2491-2409. https://doi.org/10.1007/s10803-017-3156-7

Peirats, J., Pellicer, O., \& Marín, D. (2019). Elementos para la comunicación en un caso de inflexibilidad autista.Etic@net, 19(2), 1-25. https://doi.org/10.30827/eticanet.v19i2.11847.

Pérez, L., Guillén, A., Pérez, M. P., Jiménez, I., \& Bonilla, M. J. (2012). La atención educativa al alumnado con Trastorno del Espectro Autista. Consejería de Educación.

Pinel, V., Aguiló, L., \& Adrover, D. (2018). Los robots sociales como promotores de la comunicación en los Trastornos del Espectro Autista (TEA). Letras de Hoje, 53(1), 39-47. https://doi.org/10.15448/ 1984-7726.2018.1.28920

Pouw, L. B., Rieffe, C., Ossterveld, P., Huskens, B., \& Stockmann, L. (2013). Reactive/proactive aggression and affective/cognitive empathy in children with ASD. Research in Developmental Disabilities, 34(4), 1256-1266. https://doi.org/10.1016/j.ridd.2012.12.022

Premack, D., \& Woodruff, G. (1978). Does the chimpanzee have a theory of mind? Behavioral and Brain Sciences, 1(4), 515-526. https://doi.org/10.1017/S0140525X00076512

Sanromà-Giménez, M., Lázaro-Cantabrana, J. L., Rodríguez, M., \& Gisbert-Cervera, M. (2021). Design and validation of an assessment tool for educational mobile applications used with autistic learners. Journal of new approaches in educational research, 10(1), 101-121. https://doi.org/10.7821/naer. 2021.1.574

Silva, G., \& Rodríguez, F.P. de. (2018). Una mirada hacia las TIC en la educación de las personas con discapacidad y con Trastorno del espectro autista: Análisis temático y bibliográfico. EDMETIC, Revista de Educación Mediática y TIC, 7(1), 43-65. https://doi.org/10.21071/edmetic.v7i1.10030 
Smith, E., Toms, P., Constantin, A., Johnson, H., \& Brosnan, M. (2020). Piloting a digitally-mediated social story intervention for autistic children led by teachers within naturalistic school settings. Research in Autism Spectrum Disorders, 75, 101533. https://doi.org/10.1016/j.rasd.2020.101533

Sofian, N.M., Hashim, A. S, \& Ahmad, W.F.W. (2016, April). A review on usability guidelines for designing mobile apps user interface for children with autism [conference session]. 3rd international conference on applied science and technology, Georgetown, Penang, Malaysia. https://doi.org/10. $1063 / 1.5055496$

Sofian, N. M., Hashim, A. S., \& Ahmad, W. F. W. (2018). Usability guidelines for designing mobile apps user interface for children with autism: A systematic literature review. International Journal of Engineering \& Technology, 7(4), 282-288 https://bit.ly/3Bty39P

Suárez, F., Mata, B., \& Peralbo, M. (2015). Valoración de un programa de intervención para niños con TEA basado en las TIC. Revista de Estudios e Investigación en Psicología y Educación, 9, 94-98. https://doi.org/10.17979/reipe.2015.0.09.650.

Sung, M.J. (2018, June). A study of social skills intervention for children with ASD using learning apps [conference session]. 13th international conference on e-learning. University of Technology Cape Town, South Africa. https://bit.ly/3CSDh0s. Accessed 30 Oct 2020.

Sweidan, S.Z., Salameh, H., Zakarneh, R., \& Darabkh, K.A. (2019). Autistic innovative Assistant (AIA): An Android application for Arabic autism children. Interactive Learning Environments. https://doi. org/10.1080/10494820.2019.1681468

Teixeira, L., \& Cunha, M. (November, 2019). 123 Autismo: Um aplicativo móvel para auxiliar no ensino de habilidades iniciais da matemática a crianças com autismo [Conference session]. VIII Congresso Brasileiro de Informática na Educação, Brasilia, Brazil. https://doi.org/10.5753/cbie.wcbie.2019. 1172

Terrazas, M., Sánchez, S., \& Becerra, M.T. (2016). Las TIC como herramienta de apoyo para personas con Trastorno del Espectro Autista (TEA). Revista nacional e internacional de educación inclusiva, 9(2), 102-136. https://dialnet.unirioja.es/servlet/articulo?codigo=5600282. Accessed 30 Oct 2020.

Tsikinas, S., \& Xinogalos, S. (2020). Towards a serious games design framework for people with intellectual disability or autism spectrum disorder. Education and Information Technologies, 25, 34053423. https://doi.org/10.1007/s10639-020-10124-4

Villén, M. (2017). El ocio inclusivo para personas con TEA (Trastorno del Espectro Autista) a través del Club Minecraft. In D. Muriel y R. San Salvador (Eds.), Tecnología digital y nuevas formas de ocio (pp. 157-170). University of Deusto.

Vlachou, J. A., \& Drigas, A. (2017). Mobile technology for students \& adults with autistic Spectrum disorders (ASD). International Journal of Interactive Mobile Technologies, 11(1), 4-17. https://doi. org/10.3991/ijim.v11i1.5922

Vyshedskiy, A., Khokhlovich, E., Dunn, R., Faisman, A., Elgart, J., Lokshina, L., Gankin, Y., Ostrovsky, S., deTorres, L., Edelson, S. M., \& Ilyinskii, P. O. (2020). Novel prefrontal synthesis intervention improves language in children with autism. Healthcare, 8(4), 566. https://doi.org/10.3390/healt hcare 8040566

Wang, X., \& Xing, W. (2021). Supporting youth with autism learning social competence: A comparison of game- and nongame-based activities in 3D virtual world. Journal of educational computing research. https://doi.org/10.1177/07356331211022003.

Wing, L. (1998). El autismo en niños y adultos. Una guía para la familia.

Xanthopoulou, M., Kokkalia, G., \& Drigas, A. (2019). Applications for children with autism in preschool and primary education. International Journal of Recent Contributions from Engineering, Science \& IT, 7(2), 4-16. https://doi.org/10.3991/ijes.v7i2.10335

Publisher's note Springer Nature remains neutral with regard to jurisdictional claims in published maps and institutional affiliations. 